\title{
Legal Culture as a Condition for Sustainable Development of Ukrainian Society
}

\author{
By Vira Kachur ${ }^{1}$, Svitlana Khomiachenko ${ }^{2}$, Khrystyna Moriak-Protopopova ${ }^{3}$, \\ Liudmyla Protosavitska ${ }^{4}$
}

\begin{abstract}
At the beginning of the 21 st century mankind was confronted with such global challenges in various spheres of life as environmental problems, starvation and impoverishment of the majority of the world population, degradation of morality, increasing regional and interethnic conflicts, terrorism and others. The idea of sustainable development is the answer to these challenges today. Legal culture is one of the conditions for sustainable development of Ukrainian society. It allows to rethink the role and importance of state and legal institutions for ensuring sustainable development both at the ordinary and scientific level. This role is revealed by the tasks performed by the legal culture. The formation of the philosophy of sustainable development of the population, an understanding of the values and needs of stakeholders, the involvement of individuals in the system of legal values, and legal support for all activities aimed at achieving the sustainable development goals defined in the final document of the UN Summit on Sustainable Development "Transforming our World: The 2030 Agenda for Sustainable Development" are among them. Carrying out legal socialization of various subjects of public life, developing an appropriate legal position for them will allow achieving social justice, building the foundations of inclusive development, ensuring the rule of law, eradicating corruption and restoring confidence in the state and its institutions, strengthening social cohesion, ensuring the interaction of state bodies with the public and self-organizing activities of citizens.
\end{abstract}

Keywords: sustainable development, legal culture, consciousness, life position, social orientation, consciousness, life position, social orientation, legal values

\section{Introduction}

Whenever a society faces new challenges, there is a rethinking of the concept of sustainable development of society and the role of state and legal phenomena in its provision. We can observe such a rethinking both at the day-to-day and at the scientific level. But regardless of the level at which this rethinking takes place, legal culture will be the link between them. It plays an important role not only in the formation of civil society, in the life of the individual and in the history of mankind in general, but also serves as a condition for the sustainable development of society.

At present, there is no coherent concept of legal culture in Ukraine. This leads to the lack

\footnotetext{
1 $1 \mathrm{PhD}$., Associate Professor, Head of the Department of State and Law of the National University of Life and Environmental Sciences of Ukraine

2PhD., Associate Professor of the Department of Theory and History of State and Law of the National University of Life and Environmental Sciences of Ukraine

${ }^{3} \mathrm{PhD}$., Associate Professor of the Department of History of Law, State and Political and Legal Studies of Ivan Franko National University of Lviv

${ }^{4} \mathrm{PhD}$., Associate Professor of the Department of State and Law of the National University of Life and Environmental Sciences of Ukraine
} 
of proper legal basis in the formation and implementation of cultural and legal policy of the state. Therefore, the elaboration of a strategy for the development of legal culture is becoming a priority. It will enable the formation of legal culture functions not only in the implementation of national security policy in the socio-economic, political and regional spheres of public life, preservation of historical heritage and national identity of Ukraine, overcoming both internal (weak social dialogue and social cohesion) and external (annexation of territories, military conflicts) threats to its sustainable state-legal development.

The role of the legal culture, which it performs today, is fully revealed by its tasks: 1) preservation and accumulation of legal experience (the so-called "legal memory"); 2) the transfer of legal experience from generation to generation (the so-called "legal progress"); 3) involvement of the individual in the system of legal values (the so-called "legal socialization") (Kachur, 2019). Carrying out legal socialization of various subjects of public life, development of an appropriate legal position for them will allow achieving social justice, building the foundations of inclusive development, ensuring the rule of law, eradicating corruption and restoring confidence in the state and its institutions, strengthening social cohesion, ensuring the interaction of state bodies with the public and self-organizing activities of citizens (Kachur, 2020; Shkurti, 2019; Ladychenko, 2020).

Speaking of legal culture as a condition for the sustainable development of Ukrainian society, we will show that it is covered by the concepts of "sustainable development of Ukrainian society" and "legal culture", and we will also reveal the role of legal culture in ensuring the sustainable development of society.

\section{Sustainable Development: International and National Dimensions}

The idea of sustainable development was facilitated by globalization processes. Despite its positive importance for economic and human development, globalization has also brought risks and threats. The Roman Club in 1972, in D. Meadows' report "The Limits to Growth", concluded that the depletion of natural resources in the 1920s will inevitably lead to an environmental disaster. Established in 1983 on the initiative of the Secretary-General of the United Nations, the International Commission on Environment and Development, led by G.H. Brundtland, four years later presented the report "Our Common Future", in which it first formulated the idea of sustainable development - a development capable of meeting the needs of present without jeopardizing the ability of future generations to meet their own needs. Sustainable development is based on two key components - the concept of needs and the concept of constraints.

Since 1987, the idea of sustainable development has begun to develop intensively. And as early as 1992, at the UN Conference in Rio de Janeiro, it finds refinement and concretization in the Agenda for the 21 st Century, which became the first global action program to integrate economic, social and environmental goals. Each subsequent meeting specified the principles and goals of sustainable development, defined fundamental values, envisaged urgent tasks for the international community, imposed obligations on representatives, and approved appropriate plans for implementation of decisions. 
The last document that defined the new action plan of the international community for the next 15 years was the Resolution of the UN General Assembly of September 25, 2015. "Transforming our World: The 2030 Agenda for Sustainable Development", which includes 17 sustainable development goals and 169 tasks (Assembly Resolution, 2015). In addition, paragraph 73 of the Resolution clearly provides for their implementation at three levels - at national, regional and global (Assembly Resolution, 2015). And already on September 15, 2017, the Government of Ukraine submitted the National Report "Sustainable Development Goals of Ukraine", which determined the basic indicators for achieving the sustainable development goals. The 86 national development goals and 172 indicators for their monitoring presented in the report reflect the adaptation results of 17 global sustainable development goals taking into account the development of Ukraine (Goals, 2017).

However, compliance with the SDG for the period until 2030 received its high-level insuring only in the fall of 2019. It was then that the President of Ukraine in his Decree "On the Sustainable Development Goal of Ukraine for the period until 2030" dated September 30, 2019 № 722/2019, decided that the sustainable development gоals фку "the guidelines for the development of draft forecast and program documents, draft regulatory legal acts on the goal of ensuring a balance of economic, social and environmental dimensions of sustainable development of Ukraine" (Decree, 2019).

However, Ukrainian scientists from different fields of knowledge have been dealing with the problem of sustainable development for a long time. For the most part, scientific research is devoted to the interpretation of the concept of "sustainable development", reveals various practical aspects of its understanding, and even suggest highlighting additional components of this concept. As is known, all sustainable development goals reflect the three main components of the concept of sustainable development economic (economy), environmental (environment) and social (human). As the concept of sustainable development is a complex category, it is proposed to be complemented by three more components: legal, political and national identity. The legal and regulatory component will be focused on ensuring economic security, bearing responsibility for violations, establishing control over the observance of the rules for use of natural goods and resources. The art of managing and building relationships between different social groups, states and peoples, linked to decision-making in different sectors of the economy and public life, will be placed on the political component, and national identity will be oriented to the level of human consciousness, its self-identification and vision of "its" places in society, defining one's mission and role in contemporary world processes, identifying oneself in the world (Svyda, 2014).

Such attempts are not uncommon. I. Lyashchenko also believes that the triune model society, economy and environment is incomplete. Therefore, he proposes to supplement the theory of sustainable development with the fourth aspect - cultural. At the same time in the hierarchy of cultural processes the dominant position leads to mass culture (Lyashchenko, 2015).

In our opinion, the highlighting of such components does not make sense, since law, politics, national self-identification or culture can be considered rather as forms of ensuring the implementation of the concept of sustainable development at the national level. And there are many such forms. Therefore, it is necessary to speak only about the 
economic, environmental and social components of the concept of sustainable development, where the person is central.

\section{Legal Culture as a Legal Phenomenon}

The phenomenon of legal culture lies in the fact that it permeates the legal life of both subjective (legal consciousness) and objective (legal activity, legal institutions, legal regulators). When it comes to defining the concept of legal culture, we are confronted with its polysemantism and ambiguity. Therefore, we do not expect to find any unbiased principles that will help us to give a "true" definition of legal culture. But we can count on our knowledge and memory, which calls for remembering the conflicting nature of the concepts of "culture" and "law" and the complex, interdisciplinary nature of this category. We propose to define the concept of "legal culture" through the general concept of culture. By culture we understand the specific way of organizing and developing human life in specific historical contexts, which determines the social orientation and life position of participants in public life and manifests itself in values. Since legal culture is a type of general culture and represents the synthesis of law and culture, we propose to define legal culture as a specific way of organizing and developing the legal life of participants in public life in specific historical conditions, which determines the legal orientation and legal position of the subject and manifests itself in legal values (Kachur, 2019).

The following definition gives rise to the following features of this legal phenomenon: This definition enables us to distinguish the following features of the legal culture:

1) legal culture exists only in the human environment. It is consciousness, by which we understand the holistic, internally differentiated and structurally formed psychological process of cognition and reflection by a person of the world around him or her and himself or herself, that allows, firstly, to distinguish the last of the animal world, and secondly, it performs the functions of display and generation that combine a person and the world around us. When we talk about legal culture, we first of all pay attention to legal consciousness;

2) legal consciousness unites man and the world in the forms and categories of the legal culture, which is at the same time informing the human world and the external framework of legal consciousness;

3) human and legal culture are not connected directly, but through activities that allow the consciousness to generate elements of culture (subjective activity, for example, rulemaking) through consciousness and ideas while reflecting certain fragments of culture in the individual's legal consciousness (educational activity);

4) legal culture is designed to organize human life, which implies the presence of relatively consistent, structured elements that form a functional integrity and limited by spatio-temporal limits;

5) organized legal life of a person determines legal orientation and legal position of a person. Legal orientation is a person's ability to make an informed choice of his behavior and activity in the process of its socialization and integration into society and interaction with other participants in public life. Legal orientation is a component of human consciousness and a) determine the orientation of its social choice (e.g., place in the 
social structure of society), b) is an act of human expression, c) manifested in human behavior / activity; d) capable of combining three temporal dimensions - past, present and future (for example, integrating value orientations of previous generations and current trends, as well as projecting their lives into the futured) capable of combining three temporal dimensions - past, present and future (for example, integrating value orientations of previous generations and current trends, as well as projecting their lives into the future.

When characterizing a legal position as part of a legal culture, we must remember that it is a derivative of the generic concept of "life position". Having considered the meaning of its constituent words "life" and "position", we came to the conclusion that in order to fully understand the vital position, it is necessary to take into account their characteristics, which are closely interrelated, namely: 1) concerning the life of a modern person (lifestyle, sense of life, life goals, life tasks, life perspective, life strategies, life roles, life scenario, life plan, life choice); 2) those concerning its position (value, valuation, value attitudes, value orientations, worldview, experience, etc.). This allowed us to define a life position as a stable, internally conscious human readiness for certain actions, based on its values and outlook, and reflecting its attitude to other people, their formations and society in general.

Since the legal position is a manifestation of a person's life position, we propose defining a legal position as a stable, internally conscious readiness of a person for legal behavior, based on its value-legal attitudes and legal worldview and reflects his or her attitude to legal reality (Kachur, 2019).

6) the foundation of culture is legal values that encompass legal needs, legal interests and emotional and legal experiences of a person. For example, the lack of something creates a need (the need for someone or something that requires satisfaction), the need - the interest (the desire of the person to meet their needs), and the last - emotional experiences that cause the feeling of the importance of someone or something for the subject of valuation. It is legal values that allow us to turn simple emotions into lasting feelings.

Legal values often act as a basis for choosing goals and means in the exercise of certain legal activities, and contribute to the formation of legal human psychology, legal mentality, way of life of members of society, include legal experience based on certain knowledge, and legal behavior that is their emotional component. The process and procedure for assigning certain phenomena of legal value (appreciation or objection) is called legal valuation, and a person's awareness of his or her legal valuation of an object and his or her readiness to act on it in accordance with the existing system of legal values is a value-legal setting. The set of stable and fixed value attitudes of a person to the world around him or her and to himself or herself, assigned to him or her by life experience and the totality of his or her experiences, make up the value-legal orientation.

The phenomenality of legal culture as a legal phenomenon lies in the fact that it allows not only to reveal the legal in a person (legal anthropology), but also to show its value orientations (legal axiology). 


\section{The Role of the Legal Culture in Ensuring the Sustainable Development of Ukrainian Society}

The realization that modern technology alone does not create problems or solve them, first appeared at the 1980 Toronto conference "Through the 1980s: Thinking Globally, Acting Locally". Therefore, developing a scenario of environmentally sound globalization that would ensure the evolution of mankind and the environment depends on social factors for the use of scientific and technological advances (for the benefit or detriment of man and mankind), as well as on value orientations. The technological approach in the search for a model of desired social development has given way to social value (Ryzhak, 2011).

One of the conditions for the sustainable development of Ukrainian society is a legal culture, the foundation of which is legal values that cover legal needs, legal interests and emotional and legal experiences of the individual (Ladychenko, 2019). They will determine the value and legal attitudes of a person and his value and legal orientation and will be manifested in his or her legal position. The higher the level of legal culture, the more a person is ready for lawful behavior and has positive attitude to legal reality.

Since the legal position is a manifestation of a person's life position, we propose defining a legal position as a person's stable internally conscious readiness for legal behavior, based on its value-legal attitudes and legal worldview and reflects his or her attitude to legal reality.

Concerning revealing the role of legal culture in the life of society, A. Kolomiets notes that it is: firstly, a peculiar form of harmonious human development, related both to the creation of legal values, enriching the individual, and to providing society with the necessary legal conditions for a calm and orderly development; secondly, the center of the legal values accumulated by mankind. It is their keeper, breeder, generator and relayer to other spheres of public relations. Destruction of the cultural layer of law is fraught with irreparable losses in the state-political identity of the nation, the ability to create chaos and arbitrariness in public relations; thirdly, practically the only global form through which the value and originality of national legal phenomena are reproduced: statehood, law and order, the legal system (Kolomiets, 2010).

It plays an important role not only in the formation of civil society, but also in ensuring the social stability and territorial integrity of the state (Golovko, 2019; Ladychenko, 2018; Yara, 2018).

Legal culture makes it possible to rethink the role and importance of state and legal institutions in ensuring sustainable development at both the everyday and the scientific level. Among them are the formation of a philosophy of sustainable development among the population, an understanding of the values and needs of stakeholders, the involvement of individuals in the system of legal values, and legal support for all activities aimed at achieving the sustainable development goals defined in the final document of the UN Summit on Sustainable Development "Transforming our World: The 2030 Agenda for Sustainable Development". 


\section{Conclusions}

Legal culture exists only in the human environment and is designed to organize human life, it determines the legal position of a person. It encourages conscious choices and encourages integration and interaction with other members of society. Under the pressure of legal positions, legal goals are formed, which also influence the choice of the goals of legal activity. And legal activity is directly related to the development of society. The search for an effective model of social development should ensure social stability and territorial integrity of the state.

At the end of the 20th and beginning of the 21st centuries the sense of the idea of sustainable development was to equip the social life of every country and humanity as a whole and ensure further human progress without destroying the environment. We assume that the challenges caused by the Covid-19 pandemic will lead to a shift in emphasis in ensuring the sustainable development of not only Ukrainian society. Today, both economically developed and poor countries find themselves in the same situation. Therefore, humanity will have to recognize the most important value of human life. Life is not persived as a human right, but as a total experience of his being. This will lead to a rethinking and reassessment of needs, interests, etc. A high level of legal culture of the society will attest to the existing strong legal traditions. If a society cultivates respect for elders, respect for women, and respect for representatives of law enforcement agencies, firefighters and other professions of the "defender" category, this will indicate a high level of legal culture of this society, even if the country is economically poor enough. A high level of legal culture, in turn, will have a positive impact on the sustainable development of society. Ukraine is a state with strong centuries-old traditions. We have respect for the elders instilled from childhood through fairy tales, we can derive love for mother earth from domestic folklore, respect for the defenders of the fatherland comes to us through songs about the heroic past of the Cossacks and through various social media posts about heroes-defenders in the Donbass. In difficult times, a nation unites to survive, regardless of whether it is an enemy of flesh and blood or a shadowy enemy that can only be seen by RT-PCR test, for example, Sovid-19. Therefore, a coronavirus pandemic that has swept the entire planet will answer one crucial question - Is humanity able to unite in order to survive for its sustainable development?

\section{References}

Assembly Resolution 70/1 Transforming our world: 2030 Agenda for Sustainable Development: United Nations General. (2015). Retrieved from: http://sdg.org.ua/ua/resources-2/344-2030-2015.

Decree of the President № 722/2019 "Goals of Ukraine On the Sustainable Development until 2030 ". (2019). Retrieved from: https://zakon.rada.gov.ua/laws/show/722/2019

Golovko, L., Yara, O., Kutsevych, M., Hubanova, T. (2019). Environmental Policy Integration in Ukraine and the EU. European Journal of Sustainable Development, Volume 8, № 3, 221-227.

Kachur, V. O. (2019). To the definition of "legal culture", Law. Human. Environment, 10(1), 12-19.

Kachur, V. O. (2019). Legal position as a subjective part of legal culture: to a propounding question, Law. Human. Environment, 2019, 10(4), 6-12.

Kachur, V., Protosavitska, L., Zasukha, L., Golovko L. (2020). The Role of Legal Culture in Maintaining Social Stability and Countering Separatist Movements: Case of Ukraine. European Journal of sustainable development, Volume 9, № 1, 294-299. 
Kolomiets, O.A. (2010). Legal culture in the life of Ukrainian society at the present stage, MAUP Scientific Papers, 2 (25), 250-253.

Ladychenko V., Melnychuk O., Golovko L., Burmak O. (2020). Waste Management at the Local Level in the EU and Ukraine European Journal of Sustainable Development, Volume 9, № 1, 329-329.

Ladychenko, V., Golovko L. (2018). The Right to Access to Environmental Information in Ukraine and the EU. European Journal of sustainable development, Volume 7, № 3, 455-459.

Ladychenko, V., Yara, O., Uliutina, O., Golovko, L. (2019). Environmental Liability in Ukraine and the EU. European Journal of Sustainable Development, Volume 8, № 2, 261-267.

Lyashchenko, I.S. (2015). Mass culture and sustainable development of a society: problem statement, Gileya: Scientific Bulletin, 99, 213-217.

Ryzhak, L. (2011). The philosophy of the sustainable development of mankind: Textbook. Lviv.

Shkurti, A. (2019). Analysis of the Western Balkans power market prices within the entso-e framework. European Journal of Sustainable Development, Volume 8, № 1, 229-236.

Sustainable Development Goals: Ukraine. National report. (2017). Retrieved from: http://sdg.org.ua/ua/sdgs-and-governments

Svyda, I.V. (2014). Sustainable development in the context of globalization: a synergistic approach, Bulletin of the Odessa National University. Series: Economics, 19, 3 (1), 104-108.

Yara, O., Uliutina, O., Golovko, L., Andrushchenko, L. (2018). The EU Water Framework Directive: Challenges and Prospects for Implementation in Ukraine. European Journal of Sustainable Development, Volume 7, № 2, 175-182. 